Brit. J. vener. Dis. (1966), 42, 284.

\title{
OBITUARY
}

\section{FRANCIS LEO LYDON, 1899-1966}

Dr F. L. Lydon, formerly Consultant in Venereology, King's College Hospital, died in Benghazi, Libya, on June 17, 1966.

Francis Leo Lydon, born in Galway on December 27, 1899, studied medicine at University College, Galway, and the Charing Cross Hospital, London, graduating M.B., Ch.B., B.A.O. with first class honours in the University of Ireland in 1924.

He was in general practice until the outbreak of the second world war when he joined the RAMC. From 1941 to 1944 he served as a venereologist in the Middle East. In 1944, while still serving in this theatre of war, he worked for and obtained Membership of the Royal College of Physicians. After demobilization he was appointed consultant dermatologist to Plumstead and St. Leonard's Hospitals, and subsequently to Hackney, St. Alfege's, Lewisham, and St. Olave's Hospitals, London.

In 1950 he was appointed consultant venereologist and director of the Department of Venereal Diseases at King's College Hospital. During his latter years there he was troubled with ill health, but was able to continue his work in venereology and dermatology until 1964 when he retired from his London appointments to take up a post as dermatologist in Benghazi, Libya. He had great hopes that the climate there would be beneficial to his health, and it is sad to think that he had so little time to enjoy the sunshine which he loved.

During his war service Dr Lydon made a study of trichomoniasis in the male, and developed a particular interest in non-specific urethritis which he continued to study during his time at King's College Hospital. For some years before his death he was engaged in writing a book on urethritis and the significance of its systemic complications. Dr N. Rylance, who was associated with him in this, hopes to be able to prepare the work for posthumous publication.

Dr Lydon was a man of considerable charm and varied interests, and leaves many friends to regret his loss. Our sympathy is extended to his wife and daughters who survive him.

E.G.

\section{MEDICAL SOCIETY FOR THE STUDY OF VENEREAL DISEASES}

\begin{tabular}{|c|c|c|c|c|c|}
\hline \multirow[b]{2}{*}{ October: } & \multicolumn{5}{|c|}{ PROGRAMME, 1966-67 } \\
\hline & $\begin{array}{c}\text { Further Studies in } \\
\text { Infection by the } \\
\text { Bedsonia Group }\end{array}$ & $\begin{array}{l}\text { Dr E. M. C. Dunlop } \\
\text { Dr I. A. Harper } \\
\text { Dr J. W. Race } \\
\text { Dr J. D. Treharne }\end{array}$ & March: & $\begin{array}{l}\text { Symposium on Sensi- } \\
\text { tivities of Gono- } \\
\text { cocci to Antibiotics }\end{array}$ & $\begin{array}{l}\text { Dr R. R. Curtis } \\
\text { Dr C. S. Nicol } \\
\text { Dr E. Rees } \\
\text { Dr R.S. Warren }\end{array}$ \\
\hline November: & $\begin{array}{r}\text { Recent Studies in } \\
\text { Mycoplasmata }\end{array}$ & $\begin{array}{l}\text { Dr G. W. Csonka } \\
\text { Dr Ruth Lemcke }\end{array}$ & April: & $\begin{array}{l}\text { The Rise and Fall of } \\
\text { the Treponematoses }\end{array}$ & Dr Thorstein Guthe \\
\hline January: & $\begin{array}{l}\text { Venereal Diseases } \\
\text { among the Great }\end{array}$ & $\begin{array}{l}\text { Mr A. Dickson- } \\
\text { Wright }\end{array}$ & May: & $\begin{array}{l}\text { Spring Meeting in } \\
\text { Geneva (Short } \\
\text { Papers) }\end{array}$ & \\
\hline
\end{tabular}

